https://doi.org/10.48009/1_iis_2006_220-225

\title{
ANALYSIS OF FACTORS AFFECTING DECLINING CIS ENROLLMENT
}

\author{
Lissa Pollacia, Northwestern State University, pollacia@nsula.edu \\ William L. Lomerson, Northwestern State University, lomersonw@nsula.edu
}

\begin{abstract}
Anecdotal and direct enrollment evidence indicates declining enrollments in Computer Information Systems (CIS) and other computer-related fields as a major. While there is a fair amount of speculation as to what is causing this decline, there is a limited amount of targeted research that addresses the issue. The authors conducted a survey of students in introductory computer courses to try to determine the causes for the CIS enrollment decline from the student's perspective. In addition, the authors collected data concerning the information that a student used to select a college, select a major, their initial college major and the source of that information. It is the authors' hope that the results of this survey may provide initial guidance on some remediation activities that CIS programs may undertake to increase the number of students pursuing a CIS major.
\end{abstract}

Keywords: CIS Program, Computer Majors, CS/CIS, IS Programs

\section{INTRODUCTION}

A growing body of evidence indicates there is a declining interest in both Computer Science (CS) and Computer Information Systems (CIS) as a university major. If this trend continues, it will have a major impact on both academic organizations and businesses that depend upon these graduates. The authors' research has located a fair amount of speculation as to the cause of this decline but only a limited amount of targeted research. The authors believe that some of the problem lies with decisions made by students when they are still in high school or early in their college years when they are deciding on possible future careers. In this research project, the authors surveyed incoming students to determine factors that dissuaded or encouraged them to major in CIS.

\section{PROBLEM AND PURPOSE}

Most evidence points to a steady decline in the number of students who are electing to major in a computing-related field such as Computer
Information Systems (CIS), Computer Science (CS), or Management Information Systems (MIS) since 2000 [4, 9]. There is speculation that students perceive that CIS/CS/MIS (henceforth called CIS in this paper) jobs are not there, possibly due to the dotcom bust and the concern about the outsourcing of jobs to countries such as China and India.

However, according to the U.S. Department of Labor, high-level jobs that combine technical and business skills are still abundant in the U.S. The Bureau of Labor Statistics projects that the number of jobs in the industry sector Computer Systems Design and Related Services will increase by $54.6 \%$ from 2002 to 2012 [10]. In fact, the bureau predicts that eight of the 11 fastest-growing occupations through 2012 that require a bachelor's degree will be in computerrelated fields.

The decrease in CIS enrollments coupled with a large number of pending baby-boomer retirements is expected to create a substantial number of available jobs in the U.S. If there are not enough qualified graduates to fill these jobs, this robust employment demand could be stymied. While the shortage of qualified Information Technology (IT) graduates has not become a significant problem yet, it could create a problem in the near future [7].

The purpose of this research is to determine the factors that influence a student's decision concerning a CIS major by conducting a survey of students enrolled in freshman level introductory computer courses. The questionnaire examines their awareness of computer careers and the factors that influenced their choice of a computer related major or noncomputer related major. An analysis of this data may suggest some remedial actions that to be undertaken to reinvigorate enrollment in CIS courses.

\section{BACKGROUND}

According to Computing Research Association's Taulbee Survey [12], undergraduate CS degrees awarded nearly quadrupled in the early 1980 s to over 42,000 degrees per year. This was followed by a period of swift decline and a leveling off during the 1990 s of approximately 25,000 degrees per year. 
During the late 1990s, CS degree production again surged to over 43,000 in 2001. Since 2000, however, there has been a steady decline in the number of CS degrees with a total of 14,185 awarded in 2003/2004. In addition, the number of students that have declared CS as their major has declined steadily and is now 39 percent lower than in the Fall of 2000 [11].

Current figures appear to indicate that majors in CIS or MIS are also declining. Although figures are not compiled for CIS/MIS nationwide, the levels of CIS/MIS majors at the authors' university and statewide appear to mirror the trends of CS majors. The authors own CIS department has seen a 32 percent decline in CIS majors since 2000. Examination of the enrollments in CIS/MIS for other Louisiana state universities indicates that at the statewide level, there has been a 43 percent in the number of students seeking a CIS/MIS degree since 2000 .

The reasons why students are wary of majoring in a computer-related field is not well documented. Some educators, such as Robert Baskerville, professor and chair of CIS at the Robinson College of Business at Georgia State University, speculate that the dot-com bust, the outsourcing of IT jobs, and the volatility of IT stocks may be discouraging students from pursuing IT degrees [1]. Baskerville goes on to suggest: "This may be a cyclical process in the information systems job market. As the economy comes back and the demand for IT workers resumes, businesses will find a significant shortfall in skilled workers." This shortfall will spur students to flock back to CIS/MIS programs in order to take advantage of the job opportunities. Baskerville states that academia may have to wait until the popular press discovers that there is an impending shortage in the IT workforce before enrollment figures will increase.

A related study conducted at the Center for Economic Research at Chapman University in Orange California may shed some light on reasons why there are declining CIS/MIS majors [3]. Although this study did not focus singularly on CIS/MIS degrees, it analyzed data for business school degrees, both master's and bachelor's, awarded in the U.S. over the last 30 years. Conventional wisdom has held that when the economy is good, enrollments in business schools drop; and conversely, when the economy is in a slump, workers return to school and enrollments increase. However, the data did not support this widely-held conventional wisdom. The researchers found that while there is year-to-year fluctuation, there has been a steady consistent growth in business school enrollments, from 30,000 in 1973 to 120,000 in 2000. The recent decline in CIS enrollments seem to indicate that the CIS enrollments are not as heavily influenced by the general economy as business enrollments in general.

Another recent survey of faculty at universities that offer CS/MIS/CIS degrees [5] indicates that seventysix $(76.1 \%)$ of the respondents reported that enrollment had decreased in the past two years. When questioned about the reasons as to why the respondents felt that enrollment had declined at their institutions, sixty-seven (67\%) blamed the outsourcing of CS/IT jobs overseas, sixty (60\%) stated the economy in general, sixty $(60 \%)$ cited the dot.com failure, forty $(40 \%)$ indicated that the slow down was cyclical in nature, and twenty-seven (27\%) stated the decline in students' analytical abilities.

Others have speculated that negative media attention coupled with the popularity of television programs that glamorize other fields, such as criminal forensics, have influenced many students who would have once considered majoring in CS or CIS $[2,7]$.

\section{PURPOSE AND METHODOLOGY}

The purpose of this survey was to uncover some of the causes of this enrollment decline from the students' perspective. The survey queried entering students concerning their differential knowledge of the various computer career fields and the factors that influenced the selection of their college major. The authors hope that the results of this survey may suggest some remediation activities that CIS educators may undertake to increase the number of majors in their CIS program.

The authors selected students in freshman level introductory computer courses offered by the College of Business and General Studies as the target population. This group was selected on the basic assumption that at this point in their college studies they would have had the least amount of modification in their attitudes and knowledge of computer related careers and majors since leaving high school.

In selecting the items to be included in the questionnaire, the authors drew on many of the suggested causes of disinterest that were suggested in their literature review $[1,3,4,9]$. The authors also used their own experience in teaching, researching and consulting on issues important to CIS students and prospective employers. Where possible, the authors used Likert scales for question responses to enable statistical analysis of the data. After developing the initial questionnaire, the authors then 
conducted a pilot study [6] with 40 respondents from the target population. Based upon the results of the pilot study, the questionnaire was further revised to its present form.

Because the authors wished to collect the opinions of incoming students in an introductory computer course, they decided to use a web-based survey to reach the target population. The authors believe that the shortcomings of web-based surveys, which were identified by O'Malley, [8] such as demographics, technology capability, and literacy capability of the participant, appear to be non-factors in this survey given the subject matter and the target population.

\section{DISCUSSION OF RESULTS}

The survey was administered during the first two weeks of the Fall 2005 semester. Two hundred fortysix usable responses were obtained with approximately the same number of students from the business and general studies courses. One hundred forty-six of these students were freshman (30 hours or less college credit completed or in progress) and are the focus of the discussions of this paper. Even though the analytical scope in this paper is limited, the sample data does provide some interesting implications for remediating activities.

\section{Demographics}

The results of the survey show that the respondents were a diverse academic group of students rather than the compact distribution that the authors expected from a freshman level course. Half of the 246 respondents are true freshman with less than 31 hours of college credit and less than 20 years old. The remainder runs the full spectrum of age and classification. Hereinafter the term respondents refers to the selected group (less than 31 hours and less than 20 years old).

\section{Major Selection}

Tables 1, 2, and 3 give some background into the interest and attitudes of the students with regard to computer related majors. The students were asked if they had ever considered a college major dealing with computers (Table 1). If the student selected one of the choices indicating they were not in a computer related major, they were directed to a follow-on question based upon their selection. If they chose "Yes, but I did not pursue it," they were directed to the question shown in Table 2. If they chose "No," they were directed to the question shown in Table 3. One encouraging fact to emerge from this section was that $26 \%$ of the respondents had considered a computer related major, but settled upon something else. These students may be more receptive to efforts to recruit them into a CIS program.

Table 1. Did you ever consider a college major dealing with computers?

\begin{tabular}{|l|l|l|}
\hline Answer Choices (select one) & \multicolumn{2}{l|}{ Responses } \\
\hline Yes, I am currently studying a computer-related major. & 36 & $25 \%$ \\
\hline Yes, but I did not pursue it. & 38 & $26 \%$ \\
\hline No. & 71 & $49 \%$ \\
\hline
\end{tabular}

Table 2. I considered a computer-related major but did not pursue it because

\begin{tabular}{|c|c|c|}
\hline Answer Choices (select all that apply) - 38 Respondents - 51 Responses & \multicolumn{2}{|c|}{ Responses } \\
\hline I could not find enough information about computer careers. & 7 & $18 \%$ \\
\hline I thought it would be too hard. & 9 & $24 \%$ \\
\hline I thought it would be too technical. & 10 & $26 \%$ \\
\hline I didn't think I would like the work. & 17 & $45 \%$ \\
\hline I didn't think the employment prospects were good. & 5 & $13 \%$ \\
\hline Other (please specify) & 3 & $8 \%$ \\
\hline
\end{tabular}


Table 3. I did not consider a computer-related major because

\begin{tabular}{|l|l|l|}
\hline Answer Choices (select all that apply) - 71 Respondents - 82 Responses & \multicolumn{2}{|l|}{ Responses } \\
\hline I never heard any information about computer careers. & 6 & $8 \%$ \\
\hline I am not interested in technical careers. & 43 & $61 \%$ \\
\hline I don't like using computers. & 13 & $18 \%$ \\
\hline People who use computers are strange. & 1 & $1 \%$ \\
\hline I didn't think the employment prospects were good. & 2 & $3 \%$ \\
\hline I don't have access to a personal computer. & 4 & $6 \%$ \\
\hline Other (please specify) & 13 & $18 \%$ \\
\hline
\end{tabular}

There were 38 respondents to the "Yes, but I did not pursue it" follow-up question shown in Table 2. There were 51 responses, since multiple answer selections were permitted. While there was no dominating reason that emerged, the authors feel that all of the selections indicate that students lack sufficient information about computer careers to make a good decision.

There were 71 respondents and 82 responses to the "No" follow-up question shown in Table 3. Many of these selections also indicate a lack of sufficient information to make career choices. The general tone of the "Other" responses indicated a lack of personal interest in computing based activities.
Analyzing the current majors of the respondents in Table 2 (Yes, but I did not pursue it) may provide some additional insight into ways to attract students into some of the less technical areas of CIS, such as business analysis or web mastering.

\section{High School Influences}

The survey contained additional questions designed to discover the factors students used to develop their opinions and awareness of computer related majors prior to matriculation. One of these questions was "How did you select your major?" (results shown in Table 4). After examining the results, it is apparent that personally developed information plays a very important role in the student's decision-making process.

Table 4. How did you select your major?

\begin{tabular}{|l|l|l|}
\hline Answer Choices (select all that apply) - 145 Respondents - 188 Responses & \multicolumn{2}{|l|}{ Responses } \\
\hline Inputs from family & 44 & $30 \%$ \\
\hline Input from school counselor & 8 & $6 \%$ \\
\hline Inputs from peers & 12 & $8 \%$ \\
\hline Self collected inputs & 99 & $68 \%$ \\
\hline Heard about the field from books, TV, etc. & 7 & $5 \%$ \\
\hline Other (please specify) & 18 & $12 \%$ \\
\hline
\end{tabular}

Next, the authors examined the perceived effectiveness of high school counseling in providing effective guidance to college majors, especially those related to computers. Based on a cumulative comparison of the responses to all questions in this table, only $24 \%$ of the respondents answered favorably (agree or strongly agree) about their high school counseling experience. The results are shown below in Table 5 . 
Table 5. Select the designator that best describes your level of agreement with the comments about your high school counseling experience. SD - Strongly Disagree D - Disagree N - Neutral A - Agree SA - Strongly Agree

\begin{tabular}{|l|l|l|l|l|l|}
\cline { 2 - 6 } \multicolumn{1}{l|}{ S(he) gave me good ideas concerning my college major. } & DD & N & A & SA \\
\hline S(he) was knowledgeable about careers in the computing field. & 34 & 22 & 42 & 19 & 17 \\
\hline S(he) gave me good counseling concerning computer-related careers. & 26 & 27 & 54 & 13 & 14 \\
\hline Overall I am satisfied with the college and career counseling I received in high school. & 23 & 23 & 43 & 23 & 22 \\
\hline
\end{tabular}

The results of the survey also reveal that while most students are comfortable with their personal computer skills, only a few consider themselves well informed about the fields of study or career opportunities in CIS and other computer-related disciplines.

\section{SUMMARY AND CONCLUSIONS}

This paper presents the preliminary findings of a questionnaire designed to identify pre-enrollment factors that affect a student's choice of a computerrelated major in general and CIS in particular. The authors feel that the preliminary analysis contained in this paper provides encouraging indicators that there are areas to be addressed that may lead to CIS enrollment increases. The results seem to indicate that high school students are not obtaining adequate and/or accurate information concerning computerrelated majors. The results also uncovered a variety of causes for the disinterest in a computer career. Reasons that involve personal likes and dislikes (e.g., I don't like computers or I don't want a technical career) are probably not something that can be ameliorated. However, those reasons, such as lack of career information and the perception of a weak job market are areas that can be addressed proactively.

One particularly surprising result was the fact that 71 of the respondents reported choosing their major using only self-developed information. They appear to have given limited influence to family, high school counselor, peers, or the popular press. The authors initially believed that high school counselors played a large role in the student's career decision-making process, but the results indicated otherwise. The survey results show that students have a high level of dissatisfaction with their high school counseling experience. All of these factors discussed above might be addressed and improved by a CIS information campaign directed at counselors and teachers of computer classes in the high schools matriculating your students.

The survey also confirms that students have limited knowledge of the fields of study or career opportunities in CIS. This lack of knowledge might be remediated effectively by including these topics as part of introductory computer classes. This would help to counter any inaccurate information acquired by the student prior to enrolling in college and, at the same time, provide the very knowledge that the student needs to make an informed career choice at a point in their academic pursuits when this choice is still viable.

For the future, the authors plan to statistically analyze the survey data. In particular, the authors want to examine the differences between those that chose a computer related major and those that considered a computer related major but selected something else. The data set also includes additional demographic data regarding the size of the respondent's high school and its locale. These items provide additional factors for correlation analysis that could identify effective remediation targets.

\section{REFERENCES}

1. BizEd (2004, May 12) Are U.S. enrollments in IT shrinking? BizEd May/June 2004, p. 50-52, retrieved 7/15/2005 from AACSB web site: www.aacsb.edu/publications/archives/mayjune 0 4/p50-52.pdf.

2. Chabrow, E. (2004, Aug 16) By the book: Declining computer-science enrollments should worry anyone interested in the future of the U.S. IT industry. InformationWeek, August, 2004, retrieved from Information Week website on December 5, 2005: http://www.informationweek.com/shared/printab leArticleSrc.jhtml?articleID=29100069. 
3. Doti, J. L. \& Francis D. Tuggle (2005, July 12). Doing the math on B-school enrollments. BizEd July/August 2005, p. 46-50, retrieved from AACSB web site on July 20, 2005: www.aacsb.edu/publications/archives/julyaug05/ p46-51.pdf.

4. Kessler, M. (2005, May 23). Fewer students major in computer: Some fear shortage of U.S. workers, more outsourcing. USAToday, retrieved $7 / 15 / 2005 \quad$ USAToday web site: www.usatoday.com/printedition/money/2005052 3/1b_computerscience23.art.htm.

5. Lenox, T. L., Woratschek, C. R. \&. Davis, G. A. (2005, October). Exploring declining CS/IS/IT enrollments, Proc.ISECON 2005, v22, Columbus, OH, Oct. 2005.

6. Lomerson, W. \& Pollacia, L. (2005, October). Declining CIS enrollment: An examination of pre-college factors. Proc. ISECON 2005, v22, Columbus, OH, Oct. 2005.

7. Murphy, C. (2005, Oct. 3). Speak up for the IT career. InformationWeek, Oct. 3, 2005, retrieved from Information Week website on December 5, 2005:

www.informationweek.com/shared/printableArti cleSrc.jhtml?articleID=171202135.
8. O’Malley, J.R., McCraw, J.H., \& Matheson, L. (2002) Internet enhanced surveying: Should we do it? Proceedings of the Thirty Second Southeast Decision Sciences Institute, M.C. Spears (ed.), Hilton Head, NC, 2002, 150-151.

9. RedNova (2005, February 21). Computer majors shortage a warning. RedNova News, retrieved 6/14/2005 RedNova web site: www.rednova.com/news/display/?id=12961.

10. U.S. Department of Labor (2004-5) Computer Systems Design and Related Services. Career Guide to Industries, 2004-05 Edition, Bureau of Labor Statistics (2004-5) U.S. Department of Labor, retrieved from the Bureau of Labor Statistics web site on July 29, 2005: www.bls.gov/oco/cg/cgs033.htm.

11. Vegso, J. (2005, March). CS bachelor's degree production grows in 2004; Poised for decline. Computing Research News, 17(2).

12. Zweben, S. (2005, May). 2003-2004 Taulbee Survey: Record Ph.D. Production on the Horizon; Undergraduate Enrollments Continue in Decline. Computing Research News, 17(3), retrieved from Computing Research Association web site July 2, 2005: www.cra.org/CRN/articles/may05/taulbee.html. 